OPEN ACCESS

Edited by:

David K. Wright,

University of Oslo, Norway

Reviewed by:

Li Wu,

Anhui Normal University, China

Dhananjay Anant Sant,

Maharaja Sayajirao University

of Baroda, India

*Correspondence:

Xuefa Shi

xfshi@fio.org.cn

Zhengquan Yao

yaozq@fio.org.cn

Specialty section

This article was submitted to

Quaternary Science, Geomorphology

and Paleoenvironment,

a section of the journal

Frontiers in Earth Science

Received: 05 December 2020

Accepted: 17 March 2021

Published: 12 April 2021

Citation

Shi X, Yao Z, Liu J, Qiao S, Liu Y,

Li X, Fang X and Li C (2021)

Dominant Role of Sea Level on

the Sedimentary Environmental

Evolution in the Bohai and Yellow

Seas Over the Last 1 Million Years.

Front. Earth Sci. 9:638221.

doi: 10.3389/feart.2021.638221

\section{Dominant Role of Sea Level on the Sedimentary Environmental Evolution in the Bohai and Yellow Seas Over the Last 1 Million Years}

\author{
Xuefa Shi ${ }^{1,2 *}$, Zhengquan Yao ${ }^{1,2 *}$, Jianxing Liu ${ }^{1,2}$, Shuqing Qiao ${ }^{1,2}$, Yanguang Liu ${ }^{1,2}$, \\ Xiaoyan $\mathrm{Li}^{1,2}$, Xisheng Fang ${ }^{1,2}$ and Chaoxin $\mathrm{Li}^{1,2}$ \\ ${ }^{1}$ Key Laboratory of Marine Geology and Metallogeny, First Institute of Oceanography, Ministry of Natural Resources, \\ Qingdao, China, ${ }^{2}$ Laboratory for Marine Geology, Pilot National Laboratory for Marine Science and Technology, Qingdao, \\ China
}

Transgression and regression deposits from the shallow continental margin provide information on orbital-scale variations in sea level, climate change, and local tectonics. In this study, we conduct a high-resolution chronological and sedimentological analysis of a 125-m core ( $\mathrm{NHH01}$ ) drilled in the southern Yellow Sea. We developed a high-resolution age model at the orbital timescale over the last $\sim 1$ Myr by the astronomical tuning of the sediment grain size. Sedimentological analysis and environmental proxies reveal that the study area is characterized by cyclic alternations of neritic and littoral/fluvial deposits controlled by glacial-interglacial sea-level changes. These results confirm the earlier assumption that sea-level fluctuations play a dominant role in the sedimentary architecture of the southern Yellow Sea. Moreover, only low-frequency sea-level fluctuations ( 100 kyr) were preserved in the NHH01 sequence; however, additional high-frequency ( $\sim 40 \mathrm{kyr}$ ) sea-level variations were also present in the sediments of the shallower Bohai Sea. Despite the large spatial difference, this finding implies that the sedimentary environment in the eastern marginal seas of China had been influenced by the sea level as a whole over the last 1 Myr. The comparison of the sedimentary environment with other cores from the Bohai Sea, Yellow Sea, and coastal region, as well as records from Indonesia and Japan, reveals that a consistent initiation of large-scale marine transgression occurred at $\sim 0.8-1 \mathrm{Ma}$. This phenomenon was likely caused by the long duration of glacio-eustatic high sea-level stands following the Middle Pleistocene transition, which is characterized by a shift in glacial cycles from 40 to 100 kyr.

Keywords: Yellow Sea, sea level, astronomical tuning, marine transgression, orbital timescale

\section{INTRODUCTION}

The marginal seas in the western Pacific are located in the transitional zone between Eurasia and the Pacific Ocean. The sedimentary environment in this region is sensitive to glacial-interglacial sea-level oscillations during the Quaternary (Shackleton et al., 1984). The fluctuations in sea level lead to cyclic occupation of marine water on land and reworking of sediments in the continental 
margin, which is critical to understand the role of sea level in the evolution of the sedimentary environment (Reeves et al., 2008; Ridente et al., 2008; Capozzi and Negri, 2009) and its associated biogeochemical cycles (Johnson et al., 1999).

The continental shelf of eastern China is generally flat and wide, and hence, even very small sea-level changes can shift the coastline significantly, thereby affecting coastal and shelf depositional environments, which are often characterized by transgression and regression cycles (Yi et al., 2012; Shi et al., 2016; Liu et al., 2018, 2020; Yao et al., 2020). Moreover, this cyclic exposure of land area is possibly linked to the monsoon climate in East Asia. It has been suggested that the strengthening of the East Asian summer monsoon since the last deglaciation was closely related to the expanded marine setting toward the land because of the rising sea level (Li et al., 2014). Therefore, studies on transgression and regression cycles in the continental shelf of eastern China are important to understand its potential effects on regional and global climate.

The evolutionary history of marine transgression in the continental shelf of eastern China, especially when a modernlike marine setting was initiated, is still unclear. Moreover, the mechanism driving such initiation remains controversial. Yi et al. (2016) revealed that the Bohai Sea was dominated by fluvial and lacustrine settings from the late Miocene to the early Pliocene and then flooded since the late Pleistocene. This change was attributed to the tectonic subsidence of Miaodao Island, which prevented seawater intrusion during the late Miocene and the early Pliocene (Yi et al., 2016). Paleomagnetic and sedimentary environment results of a 214-m core (BH08) from the Bohai Sea showed that marine and continental depositional cycles since $\sim 1$ Ma were due to sea-level changes during the glacial-interglacial cycles (Yao et al., 2014; Shi et al., 2016). The sedimentary records from the northern East China Sea indicated that the subsidence of the Min-Zhe Uplift controlled seawater intrusion in the region since $\sim 2 \mathrm{Ma}$ (Yi et al., 2014). A 300-m long borehole (CSDP-1) from the western Yellow Sea, with a basal age of $\sim 3.5 \mathrm{Ma}$ (Liu J.X. et al., 2016), showed the occurrence of extensive transgression at $\sim 1 \mathrm{Ma}$. Before $\sim 1 \mathrm{Ma}$, this region was dominated by fluvial facies with sporadic marine deposits (Liu et al., 2018). Based on the clay mineral and Sr-Nd isotopic study of CSDP-1, Zhang et al. (2019) suggested that the tectonic subsidence of the Min-Zhe Uplift since the middle Pleistocene was the first-order control on large-scale transgression of the Yellow and Bohai seas. Gao et al. (2020) demonstrated that the widespread marine-related deposits on the coastal plain of the southern Yellow Sea were associated with the subsidence of the Min-Zhe Uplift at $\sim 0.8 \mathrm{Ma}$, which allowed the intrusion of seawater from the East China Sea to the southern Yellow Sea (Gao et al., 2020).

The Bohai Yellow seas have undergone similar environmental changes during the Quaternary, thereby providing an ideal background for studying the history of marine transgression and its underlying causes. In this study, we investigate a 125-m long core (NHH01) from the southern Yellow Sea to understand the sedimentary history over the last $\sim 1$ Myr. Our results were then combined with the published results of core BH08 from the Bohai Sea to reveal the dominant control of sea level on the sedimentary environment at the tectonicorbital timescale.

\section{GENERAL SETTINGS}

The Yellow Sea is a semi-enclosed sea located between the Chinese mainland and the Korean Peninsula, covering an approximate area of $400,000 \mathrm{~km}^{2}$ and a mean water depth of $44 \mathrm{~m}$ (He, 2006). It connects with the Bohai Sea via the Bohai Strait in the north and the East China Sea in the south (Figure 1). The entire Yellow Sea is separated into two parts by the Shandong Peninsula: the northern Yellow Sea and the southern Yellow Sea. The water depth of the southern Yellow Sea displays a general increasing trend from the northwest to the southeast (Qin et al., 1989). The Yellow Sea is dominated by the semi-diurnal tides (M2) (tidal range 2-4 m), which is mostly $1-3 \mathrm{~m}$ high, occasionally exceeding $4 \mathrm{~m}$ during typhoons and storms (Fang, 1986). The circulation pattern in the Yellow Sea is characterized by the Yellow Sea Warm Current and coastal currents (Hu, 1984).

The rivers surrounding the Yellow Sea supply a significant amount of sediment to this area, especially the Yangtze River and the Yellow River. Over 1.0 billion tons of sediments are transported by the Yellow River to the Bohai Sea annually (Milliman and Meade, 1983). Approximately 15-30\% of the sediment is transported out of the Bohai Sea and into the Yellow Sea (Alexander et al., 1991; Qiao et al., 2017). Moreover, an average of $1 \times 10^{6}$ tons/yr of sediment from the Yangtze River was transported into the Yellow Sea by the Yellow Sea Warm Current (Gao et al., 1997). In comparison with the Yellow River, other small rivers drained from the Chinese mainland and the Korean Peninsula contribute less sediment load (Lee and Chough, 1989; Yang et al., 2003). A review examining the sediment budget in the Eastern China Shelf suggests that rivers around the Yellow Sea discharge $\sim 13.0 \times 10^{6}$ tons of sediment per year, of which $\sim 50 \%$ is assumed to form the subaerial delta (Qiao et al., 2017). It is suggested that the major source of fine-grained sediment deposited in the Yellow Sea is either transportation from the Bohai Sea or erosion from the surrounding coastal areas, and the atmospheric dust contributes only $\sim 1-2 \%$ of the mud deposits in the Yellow Sea (Qiao et al., 2017). Although the eolian dust input into the Yellow Sea would be higher during the glacial periods, it can be expected that its contribution was considerably less than the fluvial input and erosion from the surrounding area (Zhou et al., 2014; Qiao et al., 2017).

The southern Yellow Sea is a Mesozoic-Cenozoic graben basin and its basement is characterized by NE- and NEE-oriented uplift-and-subsidence zones formed as a result of tectonic movements since the Mesozoic (Gilder and Courtillot, 1997). The Min-Zhe Uplift extends northeastward from southeastern China (Guangdong, Zhejiang, and Fujian provinces) through Cheju Island to the southeastern Korean Peninsula. It was uplifted in the late Mesozoic and formed a boundary between the southern Yellow Sea and the East China Sea (Jin and Yu, 1982). The basement of the Min-Zhe Uplift is dominated by the Precambrian metamorphic rocks and the Mesozoic pyroclastic rocks, underlying the Cenozoic marine sediments with thickness 


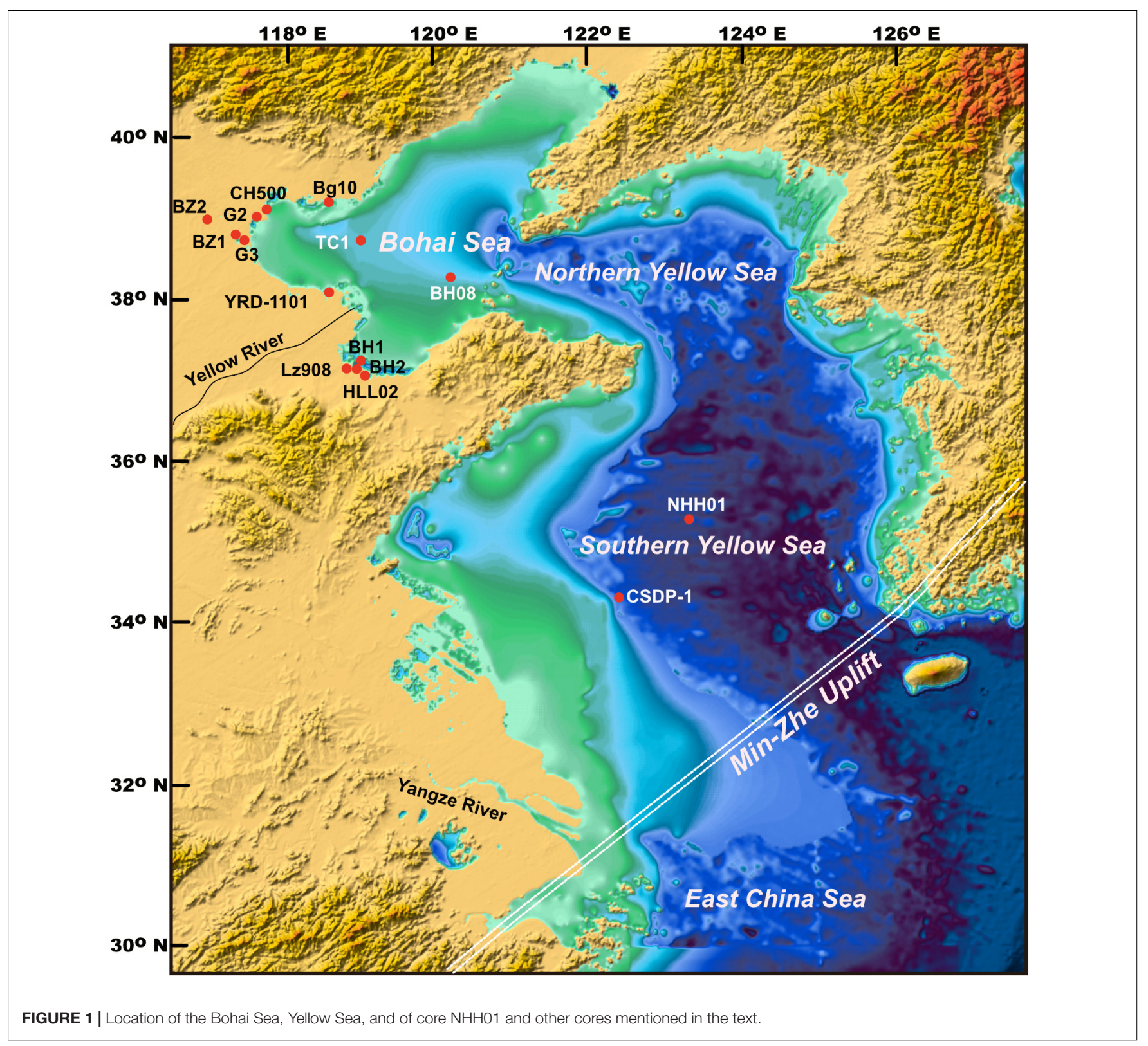

ranging from 800-1200 $\mathrm{m}$ (Jin and Yu, 1982). The estimated thickness of Quaternary sediments was $300 \mathrm{~m}$ because of the continuous subsidence since the Miocene (Qin et al., 1989; Yang et al., 2004; He, 2006), which favors the preservation of sediments.

\section{MATERIAL, METHODS, AND DATA SOURCES}

Core NHH01 (125.6 m, $123^{\circ} 13^{\prime} \mathrm{E}, 35^{\circ} 13^{\prime} \mathrm{N}$; Figure 1) was recovered from the southern Yellow Sea at a water depth of $\sim 73 \mathrm{~m}$. The approximate mean core recovery is $91 \%$.

$\mathrm{X}$-ray fluorescence (XRF) core scanning provides a nondestructive, rapid and nearly continuous analysis of elements in the sediment profile (Jansen et al., 1998). Elemental abundances in core NHH01 were obtained at $\sim 1-\mathrm{cm}$ intervals using the Itrax XRF core scanner. The color reflectance of the sediments was measured at a resolution of $\sim 1 \mathrm{~cm}$ using a hand-held spectrometer. The parameter of $\mathrm{a}^{*}$ in color reflectance is generally defined as redness, in which higher values correspond to more reddish sediments. Previous studies have indicated that the variations in $\mathrm{a}^{*}$ are mainly linked to the presence of high-valence iron oxides and hydroxides (Deaton and Balsam, 1991), which are prone to be enriched (depleted) in relatively oxidizing (reducing) environments. Sediment redness can thus indicate paleoredox conditions (Nagao and Nakashima, 1992). In previous study, benthic foraminiferal analyses were carried out for 96 samples in a previous study (Liu et al., 2014) to clarify the sedimentary environment. 

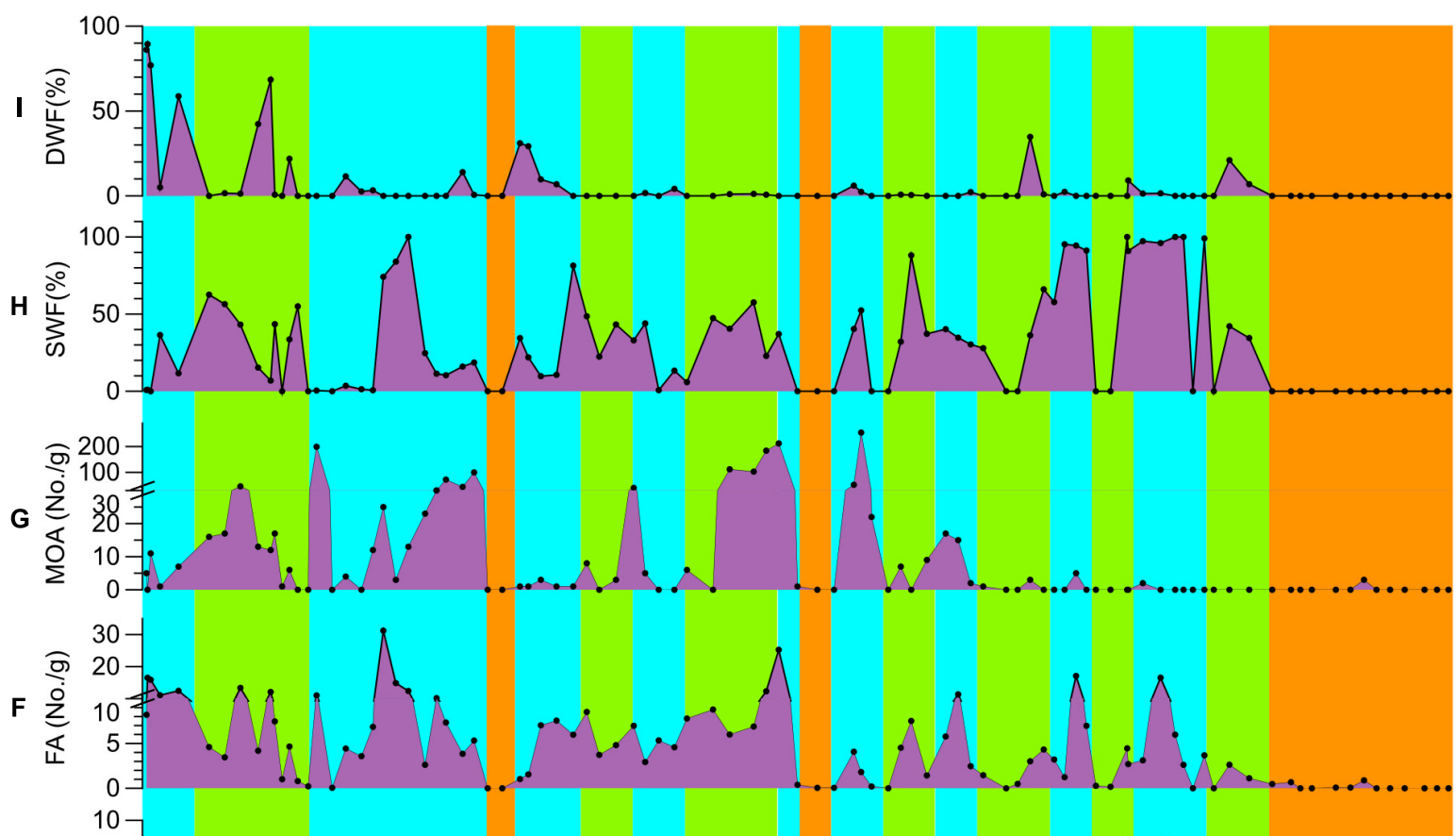

E
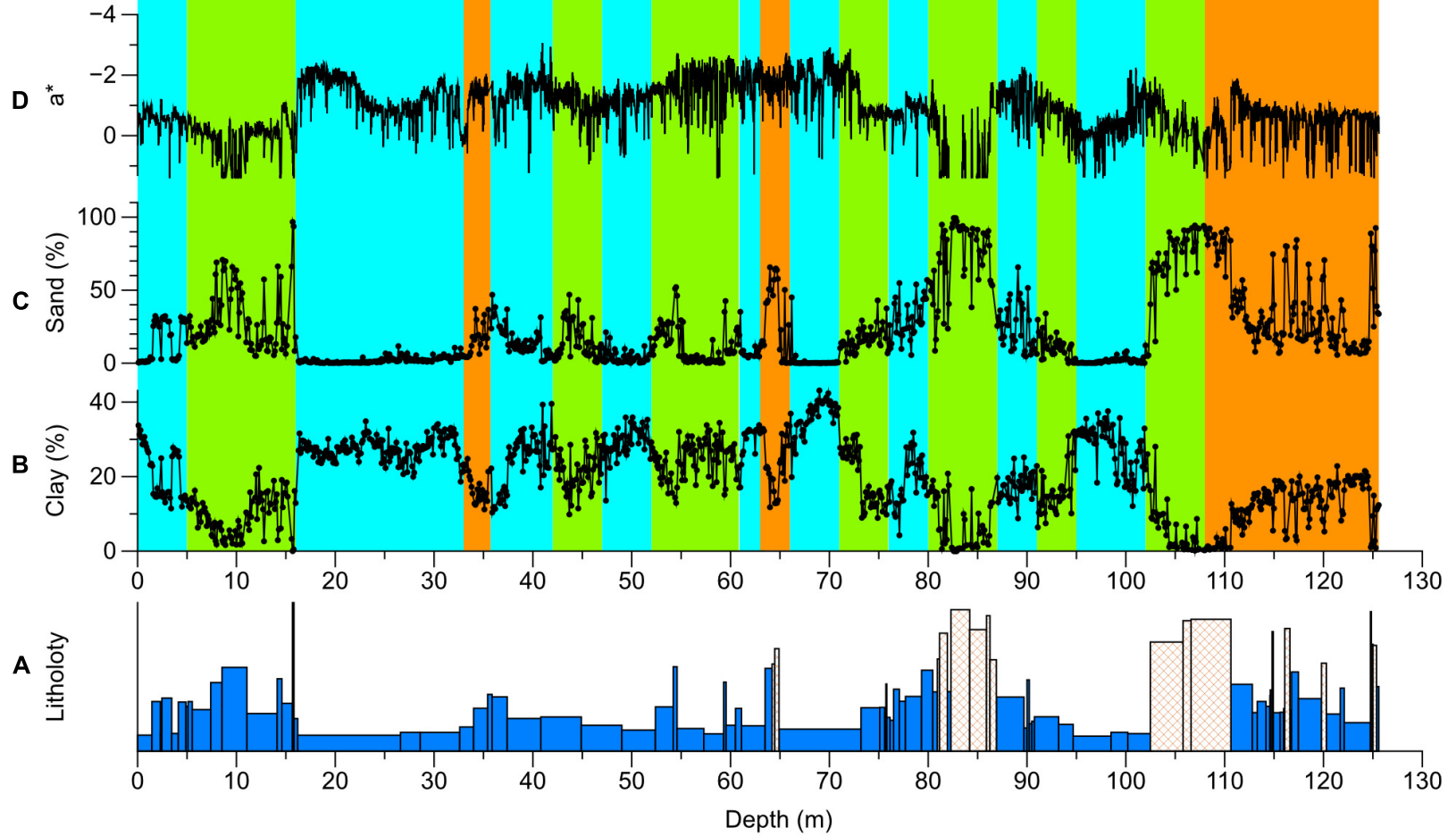

Legend

Silt/clay Sand

Fluvial deposits

Littoral deposits

neritic deposits

FIGURE 2 | Sedimentary environment and proxies of core NHH01. Lithology (A; Liu et al., 2014), clay (B) and sand content (C; Liu et al., 2014), sediment redness

$\left(\mathbf{D} ; \mathrm{a}^{\star}\right)$, XRF-scanning Fe/Si ratio (E), foraminifera abundance (F; FA, Liu et al., 2014), marine ostracods abundance (G), and fractions of shallow (H) and deep (I) water foraminifera. 
Astronomical tuning method can provide a high-resolution chronology for sedimentary sequences at orbital timescales. However, such chronology can only be developed when the lithologies or proxies in the sedimentary sequence can be correlated to orbital-forcing climatic changes. Sediment texture, such as grain size in core $\mathrm{NHH01}$, provides direct information on the sedimentary environment related to glacial-interglacial climate changes (Liu et al., 2014). Before tuning, spectral analysis was carried out on the grain size data (clay content) using the REDFIT method implemented in PAST software (Hammer et al., 2001). Bandpass filters were used to isolate the 100-kyr components of the clay time series using AnalySeries software (Paillard et al., 1996).

\section{RESULTS}

\section{Sedimentary Environment Recorded in Core NHHO1}

Lithological and microfossil data, including clay/sand content, sediment redness $\left(\mathrm{a}^{*}\right)$ and XRF scanning-derived $\mathrm{Fe} / \mathrm{Si}$ ratio, show that core NHH01 is characterized by the alternations of neritic and littoral deposits throughout the sequence (Figure 2). Core NHH01 is mostly dominated by marine-related deposits, with three layers of fluvial deposits present at $\sim 35,65$, and $\sim 108-125 \mathrm{~m}$ in the core sequence (Figure 2). Therefore, the first appearance of marine transgression occurred at $\sim 108 \mathrm{~m}$ of the core, which marks the initiation of the marine transgression in the study area. The discrimination between the neritic and littoral deposits was obtained based on the microfossil assemblages. Generally, the abundance of foraminifera was relatively high in the neritic deposits relative to the littoral settings (Figures $\mathbf{2 F}, \mathbf{H}$ ). This pattern of cyclic neritic and littoral deposits is also evidenced by the grain size and geochemical data, exhibiting high clay content, higher $\mathrm{Fe} / \mathrm{Si}$ and lower $\mathrm{a}^{*}$ (less redness) values in the neritic deposits (Figure 2). This coherency can be reasonably explained in the case of shallow marine settings, as $\mathrm{Fe}$ is prone to be enriched in fine sediments, whereas $\mathrm{Si}$ is enriched in the coarse fraction (Lin et al., 2002; Liu S. et al., 2016). Lower $a^{*}$ values in the neritic deposits suggest more reducing conditions, due to deeper water depth and high clay content in sediments.

\section{Astronomically Calibrated Chronology of Core NHH01}

The variations in the clay content of core NHH01 are closely linked to the sedimentary environment in the Yellow Sea, with high clay content in the neritic deposits and low values in the littoral deposits. Considering that the alternation of neritic and littoral deposits is related to the fluctuations in sea level, the proxy of the clay content in the NHHO1 sequence can be used as a proxy to reflect sea-level fluctuations that are linked to glacial-interglacial climate changes. This relationship was also reported in a previous study, which suggested that more clay was found in the interglacial deposits (Liu et al., 2014).

Spectral analysis of the clay content in core NHH01 in the depth domain revealed two strong cycles centered at 28.7 and $9.6 \mathrm{~m}$ (Figure 3A). Using the initial chronology established by paleomagnetic results (Liu et al., 2014) which suggested a basal age of $\sim 1.1 \mathrm{Ma}$ for the core, the cycles at 28.7 and $9.6 \mathrm{~m}$ correspond to the cycles at 253 and $84 \mathrm{kyr}$ cycles, respectively. The calculated 84-kyr cycle is further supported by the spectral analysis of clay in the time domain, which shows a 78-kyr cycle (Figure 3B). As the cycle at $78-84 \mathrm{kyr}$ is largely consistent with orbital eccentricity periods of $100 \mathrm{kyr}$, we suggest that the clay fraction in core NHH01 can be used for tuning the stratigraphic record. Thus, we used orbital eccentricity, which was calculated after the La2004 astronomical solution as a target curve (Laskar et al., 2004). We first filtered the 100-kyr signal from the clay content and correlated it with the eccentricity target curve (Figure 4B). The minimum in the filtered curve of clay, which corresponds to littoral sediments, has been correlated with minima in eccentricity (Figures 4A,B), which marks glacial sea-level lowstands. Similarly, eight additional
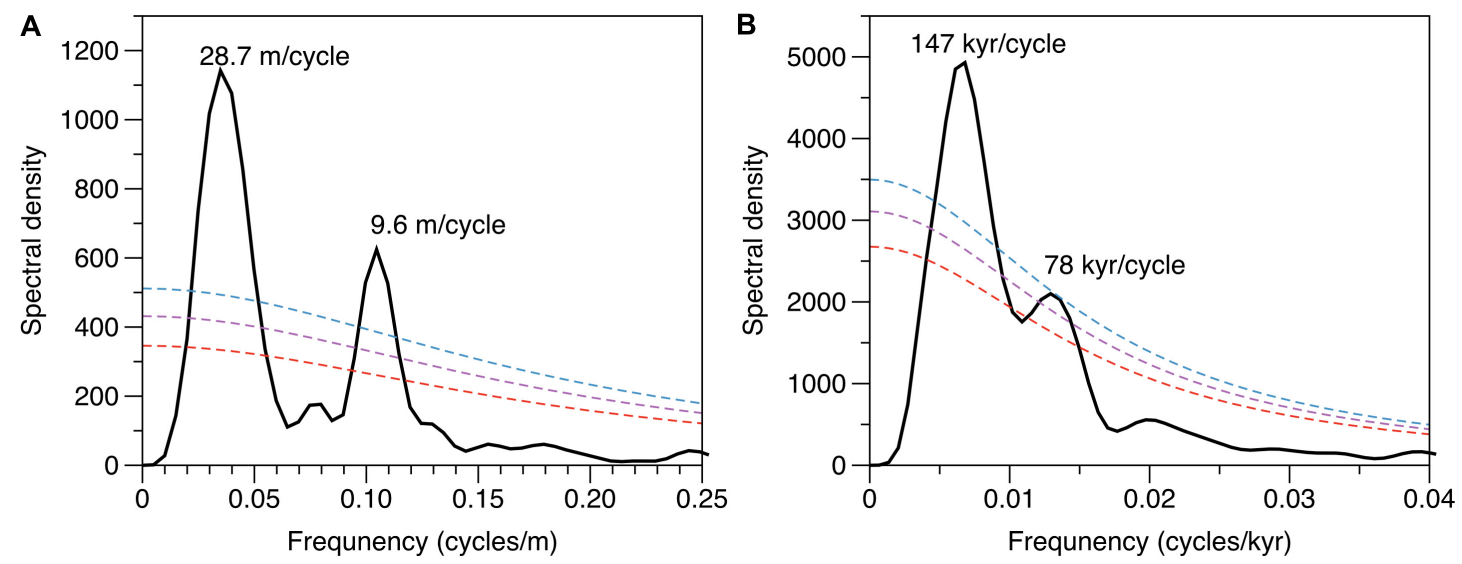

FIGURE 3 | Spectral analyses of the clay fraction from core NHH01 in depth (A) and time (B) domain against the initial age model constrained by paleomagnetic results, with their $80 \%$ (red), 90\% (purple), and 95\% (blue) significance levels indicated with dashed lines. 


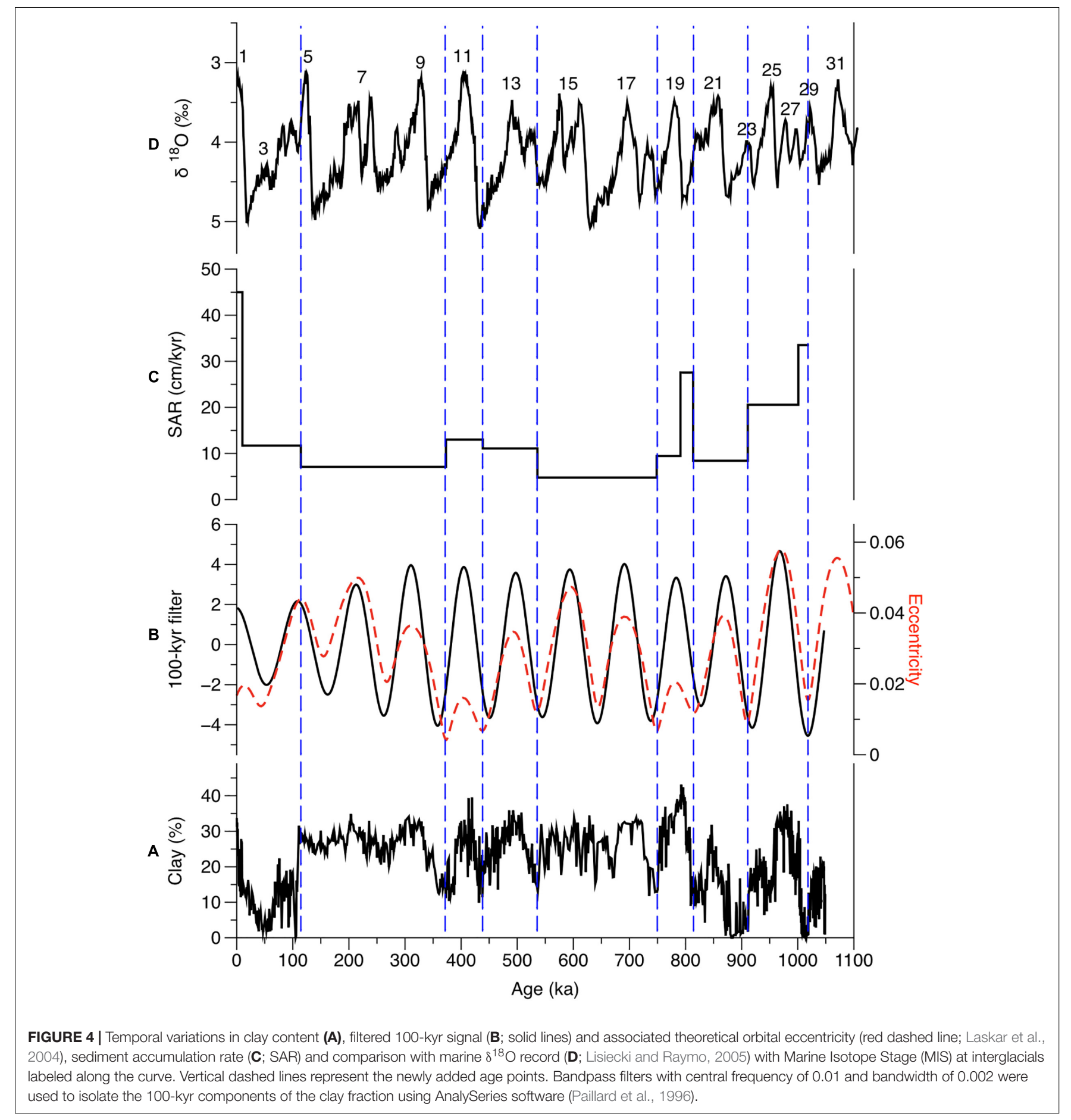

control points were used to establish the chronology. This tuning results in an almost cycle-by-cycle correlation of the variations in clay with the marine $\delta^{18} \mathrm{O}$ record (Lisiecki and Raymo, 2005; Figures 4A,D). The mean sediment accumulation rate (SAR) was calculated based on the tunned age model at the orbital timescale. In general, the SAR was relatively high during most of the interglacial periods and was lower during the glacial periods (Figure 4C).

\section{DISCUSSION}

\section{Initiation and Implication of the}

\section{Large-Scale Transgression in the} Continental Shelf of Eastern China

The analysis of the sedimentary environment suggests that the study area was dominated by the alternating of neritic 
and littoral deposits during the last $\sim 1.05 \mathrm{Ma}$ (Figure 2). The initiation of the marine transgression occurred at $\sim$ $1 \mathrm{Ma}$, which is largely consistent with the results from the Yellow Sea and Bohai seas (Figure 5). The comparison of sedimentary facies/environment of cores from the western Yellow Sea (CSDP-1; Liu et al., 2018), Bohai Sea (BH08; Yao et al., 2014; Shi et al., 2016) and Bohai coastal area (BH1, BH2, HLL02x, Lz908, and BZ2; Yao et al., 2010, 2012; Yi et al., 2015, 2016) reveals that the occurrence of large-scale marine-dominated deposits in this region initiated at $\sim 0.8-1 \mathrm{Ma}$, marking the formation of the modern-like sedimentary environment.

Regarding the cause of the initiation of the large-scale marine transgression, previous studies from the Bohai Sea, southern Yellow Sea, and East China Sea consistently revealed that large-scale marine transgression occurred at $0.8-1 \mathrm{Ma}$ and was attributed to the subsidence of the Min-Zhe Uplift
(Yi et al., 2014; Zhang et al., 2019; Gao et al., 2020). Before $\sim 0.8 \mathrm{Ma}$, the Min-Zhe Uplift was high enough to prevent seawater intrusion. Thereafter, the subsidence of the Min-Zhe Uplift facilitated the marine transgression into the Yellow Sea. However, we argue that the initiation of the large-scale marine transgression in the continental shelf of eastern China was not necessarily linked to the subsidence of the Min-Zhe Uplift, based on the following evidence. In core CSDP-1, the first appearance of marine deposits was found at $\sim 1.66 \mathrm{Ma}$ (Liu et al., 2018), which was considerably earlier than $\sim 0.8-1.0$ Ma. Moreover, no reliable evidence indicates the subsidence of the Min-Zhe Uplift at that time. Second, magnetostratigraphy and sedimentary environment studies from the Osaka Bay, southwestern Japan, suggest that the first seawater intrusion occurred during a period of high sea level that corresponded to the marine oxygen isotope stage $37(\sim 1.2 \mathrm{Ma}$; Biswas et al., 1999; Kitaba et al., 2011). Paleomagnetic, diatom, and

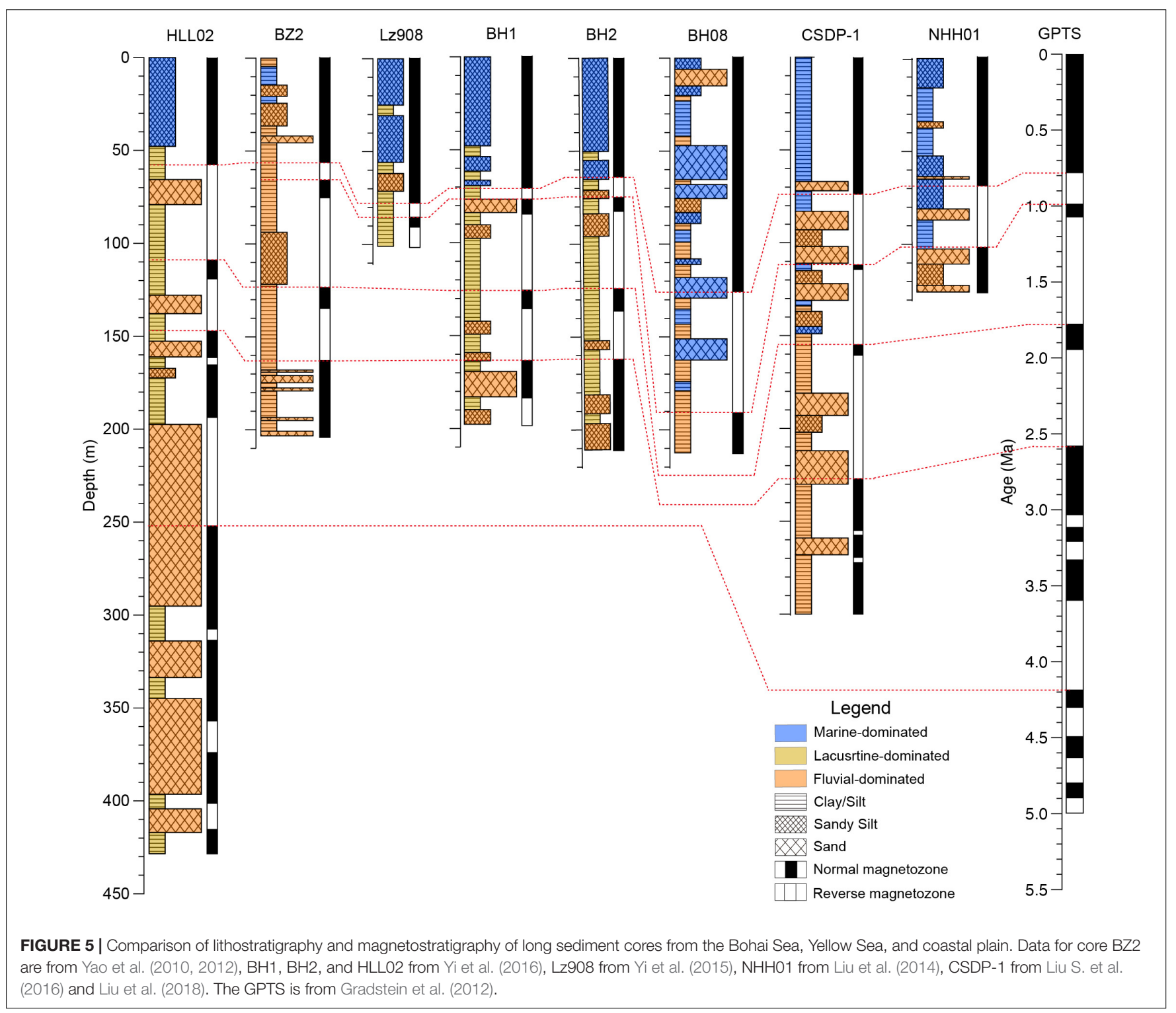


sedimentology analyses from Sangiran in central Java, Indonesia, revealed that the first major marine transgression occurred after the Olduvai event at $\sim 1.7 \mathrm{Ma}$, followed by the second one just before the Jaramillo event at $\sim 1.1$ Ma (Yokoyama and Koizumi, 1989). These two marine transgressions can be correlated with those of the marine deposits in the Yellow Sea and the Osaka Bay. These findings suggest that the initiation of the large-scale marine transgression also occurred at $\sim 1 \mathrm{Ma}$ in the entire western Pacific and was not related to the tectonic subsidence event of the Min-Zhe Uplift. Thus, we suggest that the glacio-eustatic sea level associated with the Middle Pleistocene transition (MPT) was responsible for the initiation of the marine transgression in the continental shelf of eastern China. The MPT is characterized by a transition of ice-age cyclicity from 41 to $100 \mathrm{kyr}$, as well as an increased amplitude of $\delta^{18} \mathrm{O}$ (Ruddiman et al., 1989) and decreased sea-level stands (Lambeck et al., 2002). The increased duration of high sea level under 100-kyr glacial cycles likely facilitated the inundation of more land area by the seawater during the interglacial periods, and eastern China had subsided since the Miocene (Qin et al., 1989; Yang et al., 2004).

The comparison of SAR in cores from the coastal and offshore areas suggests high SAR for offshore cores (BH08, CSDP-1, and NHH01) prior $\sim 0.78 \mathrm{Ma}$ than for the last $\sim 0.78 \mathrm{Ma}$ (Figure 6). This scenario is opposite for cores from the shallow coastal region that has higher SAR during the time interval of $0-0.78 \mathrm{Ma}$ (Figure 6). These contrasting SAR patterns imply that the depositional locus across the MPT was likely shifted from the offshore to the coastal region owing to increased accommodation space caused by longer high sea-level periods under 100-kyr glacial cycles. This observation further highlights the significant control of the MPTmodulated sea level on the sedimentation of this region at the tectonic timescale.
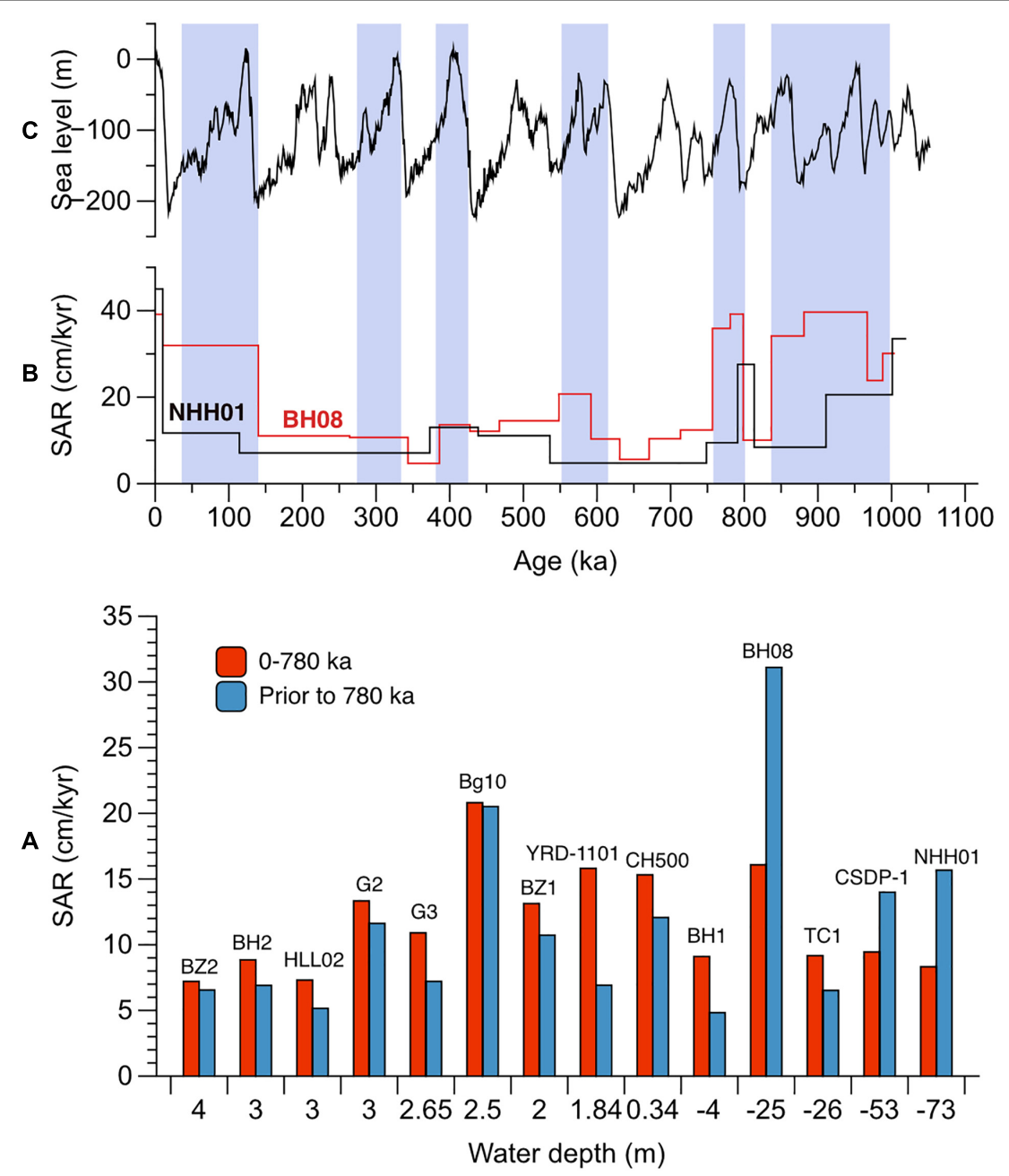

FIGURE 6 | Sedimentary accumulation rates (SAR) at the tectonic (A) and orbital (B) timescale for cores from the Bohai Sea, Yellow Sea, and coastal plain, and comparison with the global sea-level curve (C; Miller et al., 2005). Data for core BZ2 are from Yao et al. (2010, 2012), BH1, BH2, and HLLO2 from Yi et al. (2016). Lz908 from Yi et al. (2015), NHH01 from Liu et al. (2014), CSDP-1 from Liu S. et al. (2016), Liu et al. (2018); BZ1 from Xiao et al. (2008), TJC-1 from Li et al. (2016) YRD-1101 from Liu et al. (2020), CH500 from Pei et al. (2016), Bg10 from Yuan et al. (2014), G2 from Xiao et al. (2014), G3 from Yang et al. (2020). 


\section{Sea-Level Controls of the Sedimentary Environment at Orbital Timescale}

The climate during the Quaternary was marked by glacial and interglacial alternations (Shackleton et al., 1984), which led to significant sea-level fluctuations (Lambeck et al., 2002). In addition, regional and local tectonic activity might have influenced the sea-level changes (Miller et al., 2005). However, the potential influence of tectonics generally works at longer timescales ( $>10^{7}$-year scale; Miller et al., 2005), and previous results from this region suggested that sea level plays a dominant role in controlling the changes in transgression and regression environmental change (Liu et al., 2014, 2018; Shi et al., 2016). According to the results of core NHH01, the study area was dominated by the alternation of the littoral and neritic deposits during the last $\sim 1 \mathrm{Ma}$ (Figures 2, 7). Based on the tuning chronology, the neritic deposits corresponded to the highest sea-level stands during the interglacial periods, whereas the littoral deposits corresponded to the moderate sealevel stands. In the entire NHHO1 sequence, we found that only three fluvial-related layers occurred during the MIS 10,

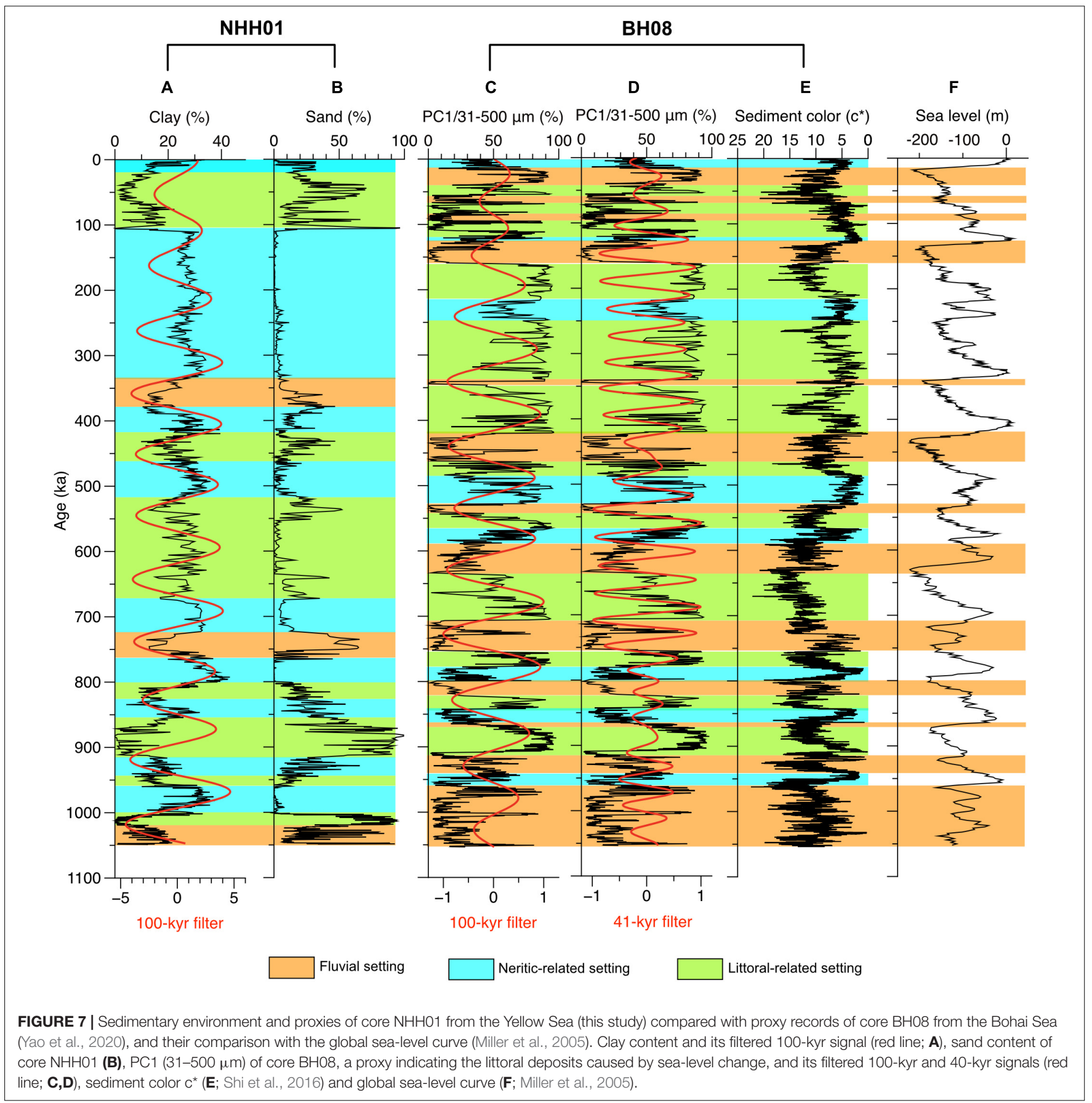


MIS 18, and MIS 30 (Figure 7) when sea-level stands were low (Miller et al., 2005).

Sediment cores from the Bohai Sea (Qin et al., 1989; Yao et al., 2014; Shi et al., 2016; Li et al., 2019), Yellow Sea (Liu et al., 2014, 2018), and coastal regions (Yao et al., 2012; Yi et al., 2012, 2015) have revealed that the sedimentation in this region is characterized by the alternation of transgression and regression cycles, as a consequence of cyclic sea-level fluctuations. Our results are consistent with those of previous studies, suggesting that the climate-induced sea-level changes play a major role in controlling the sedimentary environment, which is also true for other continental margins worldwide (Amorosi and Milli, 2001; Gerdes et al., 2003; Aguzzi et al., 2007).

An interesting feature can be observed by comparing the core BH08 from the Bohai Sea with core NHH01 from the Yellow Sea. The component PC1 (31-500- $\mu \mathrm{m}$ fraction) in core BH08 (Yao et al., 2020), a proxy of littoral deposits, shows clear $\sim 100$ - and $\sim 40$-kyr cycles, whereas only $\sim 100$-kyr was found in the clay profile of NHH01 (Figure 7). We attribute this difference to the different water depths in these two areas, as large-amplitude sea-level fluctuations at $\sim 100 \mathrm{kyr}$ band were preserved both in the deep Yellow Sea $(\sim 73 \mathrm{~m})$ and shallower Bohai Sea $(\sim 25 \mathrm{~m})$, whereas secondary sea-level fluctuations that dominated at $\sim 40 \mathrm{kyr}$ were preserved only in the Bohai Sea. This inference further implies that the Bohai and the Yellow seas were strongly influenced by the glacial-interglacial sea-level changes as at least since $\sim 1 \mathrm{Ma}$.

\section{CONCLUSION}

Sedimentological and micropaleontology studies in the NHH01 sequence, along with sediment color, XRF-scanning elemental abundance data, and the tuned age model, shows the cycles of littoral and neritic deposits, which correspond to glacialinterglacial periods over the last $1 \mathrm{Ma}$. The comparison of core NHH01 with records of other cores from the Bohai Sea and the Yellow Sea suggests that the sea-level fluctuations played a dominant role in the sedimentary architecture of this region. Despite the spatial differences, low-frequency sea-level variations $(\sim 100 \mathrm{kyr})$ were preserved in the Yellow Sea and highfrequency sea-level variations $(\sim 40 \mathrm{kyr})$ in the shallow Bohai Sea,

\section{REFERENCES}

Aguzzi, M., Amorosi, A., Colalongo, M. L., Lucchi, M. R., Rossi, V., Sarti, G., et al. (2007). Late quaternary climatic evolution of the arno coastal plain (Western Tuscany, Italy) from subsurface data. Sediment. Geol. 202, 211-229. doi: 10.1016/j.sedgeo.2007.03.004

Alexander, C. R., DeMaster, D. J., and Nittrouer, C. A. (1991). Sediment accumulation in a modern epicontinental-shelf setting: the Yellow Sea. Mar. Geol. 98, 51-72. doi: 10.1016/0025-3227(91)90 035-3

Amorosi, A., and Milli, S. (2001). Late quaternary depositional architecture of Po and Tevere river deltas (Italy) and worldwide comparison with coeval deltaic successions. Sediment. Geol. 144, 357-375. doi: 10.1016/s0037-0738(01) 00129-4

Biswas, D. K., Hyodo, M., Taniguchi, Y., Kaneko, M., Katoh, S., Sato, H., et al. (1999). Magnetostratigraphy of Plio-Pleistocene sediments in a 1700-m core confirming the sea-level controls on the sediment accumulation pattern in eastern China since the last $1 \mathrm{Ma}$.

A comparison of the sedimentary environment in core NHH01 with records of other cores from the Bohai and Yellow seas revealed that the large-scale marine transgression was initiated in the region at $\sim 1 \mathrm{Ma}$ ago. This timing is consistent with the sedimentary records from the Osaka Bay in Japan and central Java in Indonesia, thereby suggesting that the glacioeustatic sea-level variations plays a major role in this large-scale transgression event in the western Pacific marginal region. Thus, we propose that the extensive marine transgression that occurred at $\sim 1 \mathrm{Ma}$ was attributed to the long duration of high sea-level stands after the MPT.

\section{DATA AVAILABILITY STATEMENT}

The raw data supporting the conclusions of this article will be made available by the authors, without undue reservation.

\section{AUTHOR CONTRIBUTIONS}

XS and ZY designed the study, synthesized, analyzed the data, and wrote the manuscript with contributions from all authors. JL, SQ, and YL analyzed the data related to the sedimentology. XL analyzed the data of microfossils. XF and CL help to collect the core sample. All authors contributed to the article and approved the submitted version.

\section{ACKNOWLEDGMENTS}

This work was jointly supported by the Basic Scientific Fund for National Public Research Institutes of China (2018S01), the NSFC-Shandong Joint Fund for Marine Science Research Centers (U1606401 and 41476055), the National Program on Global Change and Air-Sea Interaction (GASI-GEOGE-03), and the Taishan Scholar Program of Shandong (XS). We thank the Editor and two reviewers for their valuable suggestions and Selvaraj Kandasamy for language improvement.

from Osaka Bay, southwestern Japan and short geomagnetic events in the middle Matuyama and early Brunhes chrons. Palaeogeogr. Palaeoclimatol. Palaeoecol. 148, 233-248. doi: 10.1016/s0031-0182(98)00185-0

Capozzi, R., and Negri, A. (2009). Role of sea-level forced sedimentary processes on the distribution of organic carbon-rich marine sediments: a review of the Late quaternary sapropels in the Mediterranean Sea. Palaeogeogr. Palaeoclimatol. Palaeoecol. 273, 249-257. doi: 10.1016/j.palaeo.2008.05.009

Deaton, B. C., and Balsam, W. L. (1991). Visible spectroscopy: a rapid method for deter- mining hematite and goethite concentration in geological materials. J. Sediment. Res. 61, 628-632. doi: 10.1306/d4267794-2b26-11d7$8648000102 \mathrm{c} 1865 \mathrm{~d}$

Fang, G. H. (1986). Tide and tidal current charts for the marginal seas adjacent to China. Chin. J. Oceanol. Limnol. 491, 1-16. doi: 10.1007/bf02850393

Gao, S., Park, Y. A., Zhao, Y. Y., and Qin, Y. S. (1997). “Transport and resuspension of fine-grained sediment over the Southeastern Yellow Sea," in Proceedings of the Korea-China International Seminar on Holocene and Late Pleistocene 
Environments in the Yellow Sea Basin, November 20-22, 1996 (Seoul: Seoul National University Press), 83-98.

Gao, X., Ou, J., Guo, S., Ji, W., Li, X., Deng, C., et al. (2020). Sedimentary history of the coastal plain of the south Yellow Sea since $5.1 \mathrm{Ma}$ constrained by high-resolution magnetostratigraphy of onshore borehole core GZK01. Quat. Sci. Rev. 239:106355. doi: 10.1016/j.quascirev.2020. 106355

Gerdes, G., Petzelberger, B. E. M., Scholz-Böttcher, B. M., and Streif, H. (2003). The record of climatic change in the geological archives of shallow marine, coastal, and adjacent lowland areas of Northern Germany. Quat. Sci. Rev. 22, 101-124. doi: 10.1016/s0277-3791(02)00183-x

Gilder, S., and Courtillot, V. (1997). Timing of the North-South China collision from the middle to late Mesozoic paleomagnetic data from the North China Block. J. Geophys. Res. 102, 17713-17727. doi: 10.1029/97jb01201

Gradstein, F. M., Ogg, J. G., Schmitz, M. D., and Ogg, G. M. (2012). The Geologic Time Scale, Volume 2. Amsterdam: Elsevier.

Hammer, Ø, Harper, D., and Ryan, P. (2001). PAST: paleontological statistics software package for education and data analysis. Palaeontol. Electron. 4, 1-9.

He, Q. X. (2006). Marine Sedimentary Geology of China. Beijing: China Ocean Press.

Hu, D. X. (1984). Upwelling and sedimentation dynamics I. the role of upwelling in sedimentation in the Huanghai sea and East China sea: a description of general features. Chin. J. Oceanol. Limnol. 2, 12-19. doi: 10.1007/bf02888388

Jansen, J. H. F., Gaast, S. J. V., Koster, B., and Vaars, A. J. (1998). CORTEX, a shipboard XRF- scanner for element analyses in split sediment cores. Mar. Geol. 151, 143-153. doi: 10.1016/s0025-3227(98)00074-7

Jin, X., and Yu, P. (1982). "Tectonics of the Yellow Sea and the East China Sea," in The Geology of the Yellow Sea and the East China Sea, ed. C. A. O. S. Iocas (Beijing: Science Press).

Johnson, K. S., Chavez, F. P., and Friederich, G. E. (1999). Continental-shelf sediment as a primary source of iron for coastal phytoplankton. Nature 398, 697-700. doi: 10.1038/19511

Kitaba, I., Harada, M., Hyodo, M., Katoh, S., Sato, H., and Matsushita, M. (2011). MIS 21 and the mid-pleistocene climate transition: climate and sealevel variation from a sediment core in Osaka Bay, Japan. Palaeogeogr. Palaeoclimatol. Palaeoecol. 299, 227-239. doi: 10.1016/j.palaeo.2010. 11.004

Lambeck, K., Esat, T. M., and Potter, E. (2002). Links between climate and sea levels for the past three million years. Nature 419, 199-206. doi: 10.1038/nature01089

Laskar, J., Robutel, P., Joutel, F., Gastineau, M., Correia, A. C. M., and Levrard, B. (2004). Astrophysics a long-term numerical solution for the insolation. Astronomy 285, 261-285. doi: 10.1051/0004-6361:20041335

Lee, H. J., and Chough, S. K. (1989). Sediment distribution, dispersal and budget in the Yellow Sea. Mar. Geol. 87, 195-205. doi: 10.1016/0025-3227(89)90061-3

Li, Q., Wu, H., Yu, Y., Sun, A., Marković, S. B., and Guo, Z. (2014). Reconstructed moisture evolution of the deserts in northern China since the Last Glacial Maximum and its implications for the East Asian Summer Monsoon. Glob. Planet. Change 121, 101-112. doi: 10.1016/j.gloplacha.2014. 07.009

Li, X., Li, R., Chen, X., Qiang, X., and Zhao, H. (2016). Quaternary magnetostratigraphy recorded in the sediments of core tjc-1 in the western Bohai sea. Quat. Sci. 36, 208-215.

Li, Y., Tsukamoto, S., Shang, Z., Tamura, T., Wang, H., and Frechen, M. (2019). Constraining the transgression history in the Bohai Coast China since the middle pleistocene by luminescence dating. Mar. Geol. 416:105980. doi: 10 . 1016/j.margeo.2019.105980

Lin, S., Hsieh, I. J., and Huang, K. M. (2002). Influence of the Yangtze river and grain size on the spatial variations of heavy metals and organic carbon in the East China Sea continental shelf sediments. Chem. Geol. 182, 377-394. doi: 10.1016/s0009-2541(01)00331-x

Lisiecki, L. E., and Raymo, M. E. (2005). A pliocene-pleistocene stack of 57 globally distributed benthic (18O records. Paleoceanography 20, $1-17$.

Liu, J. X., Liu, Q., Zhang, X., Liu, J., Wu, Z., Mei, X., et al. (2016). Magnetostratigraphy of a long quaternary sediment core in the South Yellow Sea. Quat. Sci. Rev. 144, 1-15. doi: 10.1016/j.quascirev.2016.05.025

Liu, J., Shi, X., Liu, Q., Ge, S., Liu, Y., Yao, Z., et al. (2014). Magnetostratigraphy of a greigite-bearing core from the south yellow sea: implications for remagnetization and sedimentation. J. Geophys. Res. Solid Earth 119, 74257441. doi: 10.1002/2014jb011206

Liu, J., Zhang, J., Miao, X., Xu, S., and Wang, H. (2020). Mineralogy of the core YRD-1101 of the yellow river delta: implications for sediment origin and environmental evolution during the last (1.9 Myr. Quat. Int. 537, 79-87. doi: 10.1016/j.quaint.2019.12.025

Liu, J., Zhang, X. H., Mei, X., Zhao, Q. H., Guo, X. W., Zhao, W. N., et al. (2018). The sedimentary succession of the last (3.50 Myr in the western South Yellow Sea: paleoenvironmental and tectonic implications. Mar. Geol. 399, 47-65. doi: 10.1016/j.margeo.2017.11.005

Liu, S., Shi, X., Yang, G., Khokiattiwong, S., and Kornkanitnan, N. (2016). Distribution of major and trace elements in surface sediments of the western gulf of Thailand: implications to modern sedimentation. Cont. Shelf Res. 117, 81-91. doi: 10.1016/j.csr.2016.02.002

Miller, K. G., Kominz, M. A., Browning, J. V., Wright, J. D., Mountain, G. S., Katz, M. E., et al. (2005). The phanerozoic record of global sea-level change. Science 310, 1293-1298. doi: 10.1126/science. 1116412

Milliman, J. D., and Meade, R. H. (1983). Worldwide delivery of river sediment to the oceans. J. Geol. 91, 1-21. doi: 10.1086/628741

Nagao, S., and Nakashima, S. (1992). The factors controlling vertical color variations of North Atlantic Madeira Abyssal Plain sediments. Mar. Geol. 109, 83-94. doi: 10.1016/0025-3227(92)90222-4

Paillard, D., Labeyrie, L., and Yiou, P. (1996). Macintosh program performs time-series analysis. Eos Trans. 77:379. doi: 10.1029/96eo00259

Pei, Y. D., Hus, J., Tian, L. Z., Yang, J. L., and Jiang, X. Y. (2016). Magnetostratigraphy of borehole CH500 on western coast of Bohai bay (in Chinese with English Abstract). Mar. Geol. Quat. Geol. 36, 19-28.

Qiao, S., Shi, X., Wang, G., Zhou, L., Hu, B., Hu, L., et al. (2017). Sediment accumulation and budget in the Bohai Sea, Yellow Sea and East China Sea. Mar. Geol. 390, 270-281. doi: 10.1016/j.margeo.2017.06.004

Qin, Y. S., Zhao, Y. Y., Chen, L. R., and Zhao, S. L. (1989). Geology of the Yellow Sea, 1-289. Beijing: China Ocean Press.

Reeves, J. M., Chivas, A. R., García, A., Holt, S., Couapel, M. J. J., Jones, B. G., et al. (2008). The sedimentary record of palaeoenvironments and sea-level change in the gulf of carpentaria, Australia, through the last glacial cycle. Quat. Int. 183, 3-22. doi: 10.1016/j.quaint.2007.11.019

Ridente, D., Trincardi, F., Piva, A., Asioli, A., and Cattaneo, A. (2008). Sedimentary response to climate and sea-level changes during the past (400 ka from borehole PRAD1-2 (Adriatic margin). G3 9, 1-20.

Ruddiman, W. F., Raymo, M. E., Martinson, D. G., Clement, B. M., and Backman, J. (1989). Pleistocene evolution: northern hemisphere ice sheets and north Atlantic ocean. Paleoceanography 4, 353-412. doi: 10.1029/pa004i004p00353

Shackleton, N. J., Backman, J., Zimmerman, H., Kent, D. V., Hall, M. A., Roberts, D. G., et al. (1984). Oxygen isotope calibration of the onset of ice-rafting and history of glaciation in the North Atlantic region. Nature 307, 620-623. doi: 10.1038/307620a0

Shi, X., Yao, Z., Liu, Q., Larrasoaña, J. C., Bai, Y., Liu, Y., et al. (2016). Sedimentary architecture of the Bohai Sea China over the last $1 \mathrm{Ma}$ and implications for sealevel changes. Earth Planet. Sci. Lett. 451, 10-21. doi: 10.1016/j.epsl.2016.07.002

Xiao, G. Q., Guo, Z. T., Chen, Y. K., Yao, Z. Q., Shao, Y. X., Wang, X. L., et al. (2008). Magnetostratigraphy of BZ1 borehole in west coast of Bohai Bay, Northern China. Quat. Sci. 28, 909-916.

Xiao, G. Q., Yang, J. L., Zhao, C. R., Wang, Q., Xu, Q. M., Hu, Y. Z., et al. (2014). Magnetostratigraphic chronology of G3 borehole from the coastal zones of Tianjin and its tectonic implications. Geol. Bull. China 33, 1642-1650.

Yang, J., Liang, M., Algeo, T. J., Xu, Q., Hu, Y., Yuan, H., et al. (2020). Upper Miocene-Quaternary magnetostratigraphy and magnetic susceptibility from the Bohai Bay basin (eastern China) and implications for regional volcanic and basinal subsidence history. Palaeogeogr. Palaeoclimatol. Palaeoecol. 538:109469. doi: 10.1016/j.palaeo.2019.109469

Yang, S. C., Hu, S. B., Cai, D. S., Feng, X. J., Chen, L. L., and Gao, L. (2004). Presentday heat flow, thermal history and tectonic subsidence of the East China Sea Basin. Mar. Pet. Geol. 21, 1095-1105. doi: 10.1016/j.marpetgeo.2004.05.007

Yang, S. Y., Jung, H. S., Lim, D. I., and Li, C. X. (2003). A review on the provenance discrimination of sediments in the Yellow Sea. Earth Sci. Rev. 63, 93-120. doi: 10.1016/s0012-8252(03)00033-3

Yao, Z., Guo, Z., Xiao, G., Wang, Q., Shi, X., and Wang, X. (2012). Sedimentary history of the western Bohai coastal plain since the late pliocene: implications 
on tectonic, climatic and sea-level changes. J. Asian Earth Sci. 54-55, 192-202. doi: 10.1016/j.jseaes.2012.04.013

Yao, Z., Shi, X., Liu, Q., Liu, Y., Cruz, J., Liu, J., et al. (2014). Paleomagnetic and astronomical dating of sediment core BH08 from the Bohai Sea, China: implications for glacial-interglacial sedimentation. Palaeogeogr. Palaeoclimatol. Palaeoecol. 393, 90-101. doi: 10.1016/j.palaeo.2013.11.012

Yao, Z., Shi, X., Liu, Y., Kandasamy, S., Qiao, S., Li, X., et al. (2020). Sea-level and climate signatures recorded in orbitally-forced continental margin deposits over the last 1 Myr: new perspectives from the Bohai Sea. Palaeogeogr. Palaeoclimatol. Palaeoecol. 550:109736. doi: 10.1016/j.palaeo.2020. 109736

Yao, Z., Xiao, G., Wu, H., Liu, W., and Chen, Y. (2010). Plio-Pleistocene vegetation changes in the North China Plain: magnetostratigraphy, oxygen and carbon isotopic composition of pedogenic carbonates. Palaeogeogr. Palaeoclimatol. Palaeoecol. 297, 502-510. doi: 10.1016/j.palaeo.2010.09.003

Yi, L., Deng, C., Tian, L., Xu, X., Jiang, X., Qiang, X., et al. (2016). Plio-Pleistocene evolution of Bohai basin (East Asia): demise of Bohai Paleolake and transition to marine environment. Sci. Rep. 6:29403.

Yi, L., Deng, C., Xu, X., Yu, H., Qiang, X., Jiang, X., et al. (2015). Paleo-megalake termination in the quaternary: paleomagnetic and water-level evidence from south Bohai Sea, China. Sediment. Geol. 319, 1-12. doi: 10.1016/j.sedgeo.2015. 01.005

Yi, L., Ye, X., Chen, J., Li, Y., Long, H., Wang, X., et al. (2014). Magnetostratigraphy and luminescence dating on a sedimentary sequence from northern East China sea: constraints on evolutionary history of eastern marginal seas of China since the early pleistocene. Quat. Int. 349, 316-326. doi: 10.1016/j.quaint.2014. 07.038

Yi, L., Yu, H. J., Ortiz, J. D., Xu, X. Y., Chen, S. L., Ge, J. Y., et al. (2012). Late Quaternary linkage of sedimentary records to three astronomical rhythms and the Asian monsoon, inferred from a coastal borehole in the south Bohai Sea, China. Palaeogeogr. Palaeoclimatol. Palaeoecol. 32, 101-117. doi: 10.1016/j. palaeo.2012.02.020

Yokoyama, T., and Koizumi, I. (1989). Marine transgressions on the pleistocene pecangan formation in the Sangiran area, central Java, Indonesia. Palaeogeogr. Palaeoclimatol. Palaeoecol. 72, 177-193. doi: 10.1016/0031-0182(89)90 141-7

Yuan, G. B., Xu, Q. M., Wang, Y., Yang, J. L., Qin, Y. F., and Du, D. (2014). Magnetostratigraphic studies of Bg10 borehole in northern Bohai Bay and its geological significance. Acta Geol. Sin. 88, 285-296.

Zhang, J., Wan, S., Clift, P. D., Huang, J., Yu, Z., Zhang, K., et al. (2019). History of yellow river and Yangtze river delivering sediment to the Yellow Sea since 3.5 Ma: tectonic or climate forcing?. Quat. Sci. Rev. 216, 74-88. doi: 10.1016/j. quascirev.2019.06.002

Zhou, L., Liu, J., Saito, Y., Zhang, Z., Chu, H., and Hu, G. (2014). Coastal erosion as a major sediment supplier to continental shelves: example from the abandoned old Huanghe (Yellow River) delta. Cont. Shelf Res. 82, 43-59. doi: 10.1016/j.csr. 2014.03.015

Conflict of Interest: The authors declare that the research was conducted in the absence of any commercial or financial relationships that could be construed as a potential conflict of interest.

Copyright (C) 2021 Shi, Yao, Liu, Qiao, Liu, Li, Fang and Li. This is an open-access article distributed under the terms of the Creative Commons Attribution License (CC BY). The use, distribution or reproduction in other forums is permitted, provided the original author(s) and the copyright owner(s) are credited and that the original publication in this journal is cited, in accordance with accepted academic practice. No use, distribution or reproduction is permitted which does not comply with these terms. 